\title{
Determination of Subsurface Geotechnical Properties for Foundation Design and Construction in Akenfa Community, Bayelsa State, Nigeria
}

\author{
Nwankwoala H.O. ${ }^{1}$, Amadi A.N. ${ }^{2, *}$, Ushie F.A. ${ }^{3}$, Warmate T. ${ }^{4}$, Eze C. J. ${ }^{5}$ \\ ${ }^{1}$ Department of Geology, University of Port Harcourt, Nigeria \\ ${ }^{2}$ Department of Geology, Federal University of Technology, Minna, Nigeria \\ ${ }^{3}$ Department of Geosciences, Akwa Ibom University, Ikot Akpaden, Nigeria \\ ${ }^{4}$ Geostrat International Services Limited, No. 14 Mannila Pepple Street, Port Harcourt, Nigeria \\ ${ }^{5}$ Department of Architecture, Federal University of Technology, Minna, Nigeria \\ Corresponding author: geoama76@gmail.com
}

Received June 30, 2014; Revised August 01, 2014; Accepted August 07, 2014

\begin{abstract}
This study aims at establishing the sub-soil types and profile to ascertain the geotechnical characteristics of the underlying soils in Akenfa in Yenagoa, Yenagoa Local Government Area of Bayelsa State, Nigeria and recommend appropriate foundation design and construction of projects in the area. Three (3) geotechnical boreholes were drilled at the site to obtain baseline data on geotechnical properties of the soil and water level monitoring, the boreholes were advanced with the use of a cable percussion boring rig and were terminated to a maximum depth of 30m. The particle size distributions of a number of representative samples of the cohesionless soils were determined by sieve analysis. The results show that the samples are low to medium plasticity silty clay. The lithology revealed intercalations of clay and sand in thin layers to a depth of $2.0 \mathrm{~m}$ below the existing ground level. Underlying this clay is a stratum of loose to medium dense sand and dense sand. The sand is well sorted grading from fine to medium as the borehole advances. The laboratory analysis showed that the silty clay has undrained shear strength of $48 \mathrm{kPa}$. The loose sand has a maximum SPT (N) value of 12 while the medium dense sand has maximum SPT (N) value of 28. Considering the nature of the civil structures to be sited in the area, it is anticipated the load and the moderate compressibility of this near surface silty clay and the underlying loose silty sand be supported by means of raft foundation founded within the clay layer. It is recommended that studies on the geotechnical characteristics of the area be carried out as it provides valuable data that can be used for foundation design and other forms of construction for civil engineering structures in order to minimize adverse effects and prevention of post construction problems.
\end{abstract}

Keywords: subsoils, geotechnical, foundation design, construction, engineering structures, Akenfa, Bayelsa, Nigeria

Cite This Article: Nwankwoala H.O., Amadi A.N., Ushie F.A., Warmate T. and Eze C. J., "Determination of Subsurface Geotechnical Properties for Foundation Design and Construction in Akenfa Community, Bayelsa State, Nigeria." American Journal of Civil Engineering and Architecture, vol. 2, no. 4 (2014): 130-135. doi: 10.12691/ajcea-2-4-2.

\section{Introduction}

Geotechnical investigation is undertaken to obtain information on the physical properties of soil and rock underlying a site to design a proposed structure and for repair of distress caused by subsurface condition. A geotechnical investigation will include surface and subsurface exploration in a site (Amadi et al., 2010).

Civil engineering projects are dedicated to the realization of efficient and economical works in a short time which requires an acceptable risk increasingly low. Geotechnical studies are highly important in such projects. Thus, a good estimate of the risk associated with geotechnical parameters has become a major issue since most of the new structures are located on sites with difficult conditions (Haddou et al., 2013; Youdeowei \& Nwankwoala, 2010).

The need for adequate and reliable geotechnical characterization of sub-soils is very important. This is because the impact of the imposed load is exacerbated by the thickness and consistency of the compressible layer (Oke and Amadi, 2008). This, in addition to other intrinsic factors contributes to the failure of civil engineering structures (Youdeowei \& Nwankwoala, 2013; Amadi et al, 2012). For the purpose of generating relevant data inputs for the design and construction of foundations for proposed structures, it is imperative that site(s) be geotechnically characterized through sub-soil investigation. The knowledge of the geotechnical characteristics of Akenfa in Yenagoa Local Government Area of Bayelsa 
State, Nigeria is very desirable for design and construction of foundation of civil engineering structures in order to minimize adverse effects and prevention of post construction problems. Generally, in the Niger Delta geotechnical data on the underlying soils are needed for the design of suitable foundation for structures (Ngah \& Nwankwoala, 2013; Nwankwoala \& Warmate, 2014). This study therefore, is aimed at establishing significant subsoil types and profile, determination of the stratigraphy of the superficial deposits underlying the site, determination of relevant engineering characteristics of the deposits for appropriate foundation design, their investigation/characterization of the geotechnical properties of all such sub-soils to generate the required data relevant to the foundation design and construction of structures as well as foundation recommendation for proposed structures in the area.

\subsection{Description of the study area}

The study area, Akenfa, is located in Yenagoa L.G.A in Bayelsa State with latitudes and longitudes 4 ${ }^{\circ} 55^{\prime 2} 9^{\prime \prime} \mathrm{N}$ and $6^{\circ} 15^{\prime} 51^{\prime \prime}$. The Akenfa Community in Yenagoa, Bayelsa State is within the Niger Delta region of Nigeria. The local geology of the location is composed of sediments which are characteristic of several depositional environments.
Deposits are geologically young, ranging from the Eocene to the recent Pliocene. They include river mouth bar, delta front platform, delta slope and open shelf sediments. The river mouth bar sediments generally consist of coarse grained sands which extend out in shallow water depths before merging with the sands and clays of the subhorizontal delta front platform. This platform extends seaward of up to $20 \mathrm{~km}$ in depths of up to $100 \mathrm{~m}$.

The area constitutes an extensive plain exposed to periodical inundation by flooding when the rivers and creeks overflow their banks. A prominent feature of the rivers and creeks is the occurrence of natural levees on both banks, behind which occur vast areas of backswamps and lagoons/lakes where surface flow is negligible (Youdeowei and Nwankwoala, 2010). Although various types of morphological units and depositional environments have been recognized in the area (coastal flats, ancient/modern sea, river and lagoonal beaches, sand bars/flats, flood plains, seasonally flooded depressions, swamps, ancient creeks and river channels), the area can be sub-divided into five major geomorphological units, namely: (i) active/abandoned coastal beaches (ii) saltwater, mangrove swamps (iii) freshwater swamps, backswamps, deltaic plain alluvium and meander belt (iv) dry deltaic plain with abundant freshwater swamps (SombreiroWarri deltaic plain) and (v) dry flat land and plain.

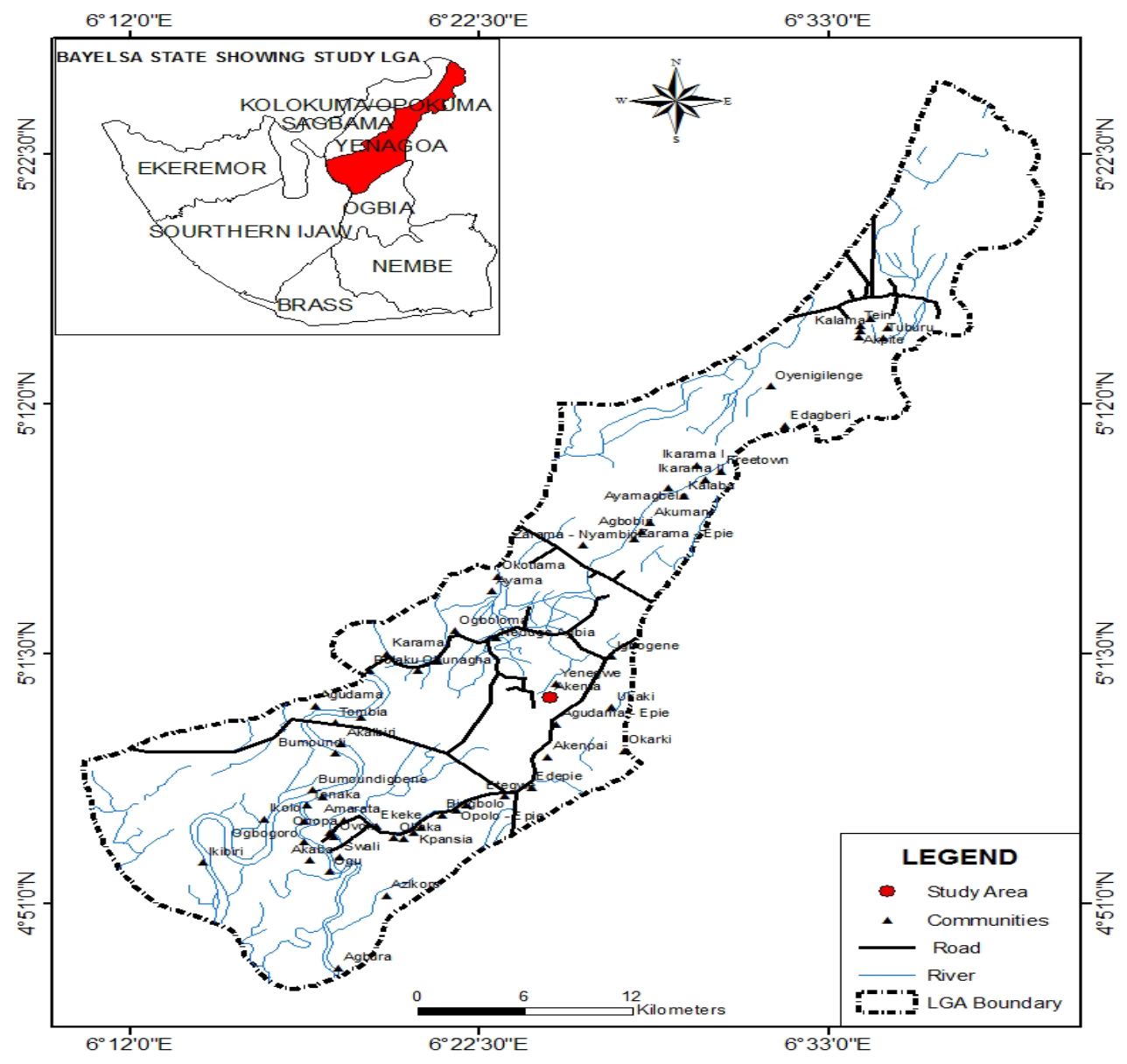

Figure 1. Map of Yenagoa Showing the Study Location - Akenfa

Our present knowledge of the geology of the Niger Delta is derived from the works of Reyment (1965), Short and Stauble (1967), Murat (1970), Merki (1970), and the exploration activities of oil and gas companies. The formation of the so-called proto-Niger Delta occurred during the second depositional cycle (CampanianMaastrichtian) of the southern Nigerian basin. However, modern Niger Delta was formed during the third and last depositional cycle of the southern Nigerian basin which started in the Paleocene. 
Generally, the Niger Delta was formed during the Tertiary period as a result of the interplay between subsidence and deposition arising from a succession of transgressions and regressions of the area. These phenomena evolved the three main lithostratigraphic units of Akata, Agbada and Benin Formations, with an overall approximate thickness of over 5,000 m of sediment body (Short and Stauble, 1967). Table 1 shows the quaternary geologic units of the study area.

Table 1. Quaternary deposits of the Niger Delta (After Etu-Efeotor \& Akpokodje, 1990)

Geologic Unit
Alluvium
Freshwater Backswamp, meander belt
Saltwater Mangrove Swamp and backswamp
Active/abandoned beach ridges
Sombreiro-warri deltaic plain
Benin Formation (Coastal Plain Sand)
Agbada Formation
Akata Formation

\section{Methods of Study}

\subsection{Borehole Drilling (Monitoring Wells)}

The investigation comprised mainly exploring three (3) geotechnical boreholes with soil sampling and measurement of water table. The boreholes were advanced using a cable percussion boring rig. All three (3) boreholes were terminated at a depth of $10 \mathrm{~m}$ below the existing ground. The hand rig is fitted with a free fall auger. The auger is lifted to a height of about $1.0 \mathrm{~m}$ above ground level, using gloved hands, and allowed to free-fall under gravity to advance the boring. As the auger falls it cuts through the soil such that the cut soil material is retained inside it by means of a clerk. The auger is then brought to the surface where the soil retained in it is emptied out. To prevent collapse of the borehole wall, the hole is lined with casings or shell corresponding to the size of the auger being used for the drilling. As the drilling continues, the auger drops into the open hole until the time sample is to be taken.

The wells were logged on site with samples recovered, representative undisturbed and disturbed samples were taken at regular intervals of $0.10 \mathrm{~m}$ depth, and also when a change in soil type was observed. The samples were used for a detailed and systematic description of the soil in each stratum in terms of its visual properties and for laboratory analysis. In the cohesive soils, a large number of undisturbed samples were taken for examination and laboratory analysis.

Field measurements of ground water showed that the groundwater levels stood at between $2.50 \mathrm{~m}$ and $3.0 \mathrm{~m}$ below the existing ground surface in all boreholes explored at the time of the field work. The water levels in the boreholes are subject to seasonal fluctuations. These values were observed during the dry season.

\subsection{Laboratory Analysis}

The physical properties of the soil samples recovered from the boreholes were examined to obtain parameters used as indices of the infiltration capacity of the soils in the area.

Detailed laboratory investigations were carried out on representative undisturbed and disturbed samples obtained from the boreholes for the classification tests and other tests. All tests were carried out in accordance with BS1377 (1990) - Methods of test for soil for civil engineering purposes, which are equivalent to the
Gravel, Sand, clay, silt

Sand, clay, some silt, gravel

Medium-fine sands, clay and some silt

Sand, clay, and some silt

Sand, clay, and some silt

medium sand; subordinate silt and clay lenses Miocene-Recent

Mixture of sand, clay and silt Clay

Eocene-Recen

American Society for Testing and Materials Standards (ASTM, 1979) Standards. Brief comments on the tests are given below:

\subsection{Soil Classification}

Atterberg consistency limit tests were carried out on the cohesive samples. The results show that the samples are low to medium plasticity silty clay. The particle size distributions of a number of representative samples of the cohesion-less soil were determined by sieve analysis. The results disclosed that the samples are predominantly, fine, fine to medium and medium sands. Laboratory consolidated tests were carried out on relatively undisturbed samples with the object of determining the compressibility properties of the soils. Test results show that the samples are of moderately high compressibility and predominantly exhibiting negligible swelling potentials.

\subsection{Consolidation Test}

In this test, the soil specimen is loaded axially in increment of applied stress. Each stress increment is held constant until the primary consolidation has ceased. During this process, water drains out of the specimen, resulting in a decrease in height, which is measured at suitable intervals. These measurements are used for the determination of the relationship between compression (or stress) or voids ratio and effective stress, and for the calculation of parameters which describe the amount of compression and the rate at which it takes place.

\subsection{Triaxial Test}

The soil was removed from its sampling tube and a careful inspection was made to ascertain its condition. The length, diameter and mass of the specimen were measured with sufficient accuracy to enable the bulk density to be calculated. The specimen to be tested was placed between the end caps in the membrane as quickly as possible to prevent loss of moisture. The membrane was placed around specimen while applying suction to the stretcher. The membrane was sealed to the end caps by means of rubber 0-ring, without entrapping air. The specimen was placed centrally on the base pedestal of the triaxial cell, ensuring that it is in correct vertical alignment was checked by allowing the piston to slide down slowly until it makes contact with the bearing surface on the top cap. The piston was retracted and the triaxial cell filled with water, ensuring that all the air is displaced through the air 
vent. The water pressure in the cell is raised to the desired value with the loading piston restrained by the load frame. The reading of force-measuring device is recorded during steady motion as the initial reading and reading of the axial deformation gauge and the valves of the axial deformation gauge are tabulated.

\section{Results and Discussion}

\subsection{Soil Stratigraphy}

The soil stratigraphy encountered in the area as obtained from the explored boreholes are presented in
Table 2. The lithology revealed intercalations of clay and sand in thin layers to a depth of $2.0 \mathrm{~m}$ below the existing ground level as presented in boreholes 1 and 2. Below this depth, the formation presents a stratum of medium dense fine sand that increases in gradation and density with depth to becoming dense fine to medium sand at about 7.0 $\mathrm{m}$ below ground level. Borehole 3 , however, revealed a $5.0 \mathrm{~m}$ thick near surface clay layer overlying the medium dense fine sand. The sand increases in density to become very dense at about $10 \mathrm{~m}$. But below this depth, at about $25.0 \mathrm{~m}$ below the existing ground level, medium dense sand is encountered again. This medium dense layer is observed to the final depth of the boring.

Table 2. The Soil Profile in the Study Area

\begin{tabular}{ccc}
\hline Stratum No. & Description & Average depth range (m) \\
\hline 1 & Clay with sand intercalations, silty, medium mottled brown and grey sand & $0-2$ \\
2 & Fine sand, silty, loose to dense, greyey clay & 30 \\
\hline
\end{tabular}

\subsection{The Near- Surface Firm Clay}

Table 3. Range of variations in the index and engineering parameters

\begin{tabular}{|c|c|c|c|}
\hline & Minimum & Maximum & Mean \\
\hline Natural Moisture Content (\%) & 18 & 39 & 26 \\
\hline Liquid Limit (\%) & 35 & 51 & 43 \\
\hline Plastic Limit (\%) & 17 & 33 & 25 \\
\hline Plasticity Index (\%) & 13 & 22 & 17 \\
\hline Liquidity Index & 0.06 & 0.71 & 0.32 \\
\hline Consistency Index & 0.94 & 0.29 & 0.68 \\
\hline Bulk Unit Weight $\left(\mathrm{kN} / \mathrm{m}^{3}\right)$ & 18.76 & 18.76 & 18.76 \\
\hline Dry Unit Weight $\left(\mathrm{kN} / \mathrm{m}^{3}\right)$ & 15.34 & 15.34 & 15.34 \\
\hline Final Void Ratio & 0.67 & 0.67 & 0.67 \\
\hline Final Porosity (\%) & 47.48 & 47.48 & 47.48 \\
\hline Undrained Strength $(\mathrm{kPa})$ & 48.0 & 48.0 & 48.0 \\
\hline Coefficient of consolidation, $\mathrm{m}^{2} / \mathrm{yr}$ & 3.66 & 5.12 & 4.22 \\
\hline $\begin{array}{l}\text { Coeff. of Compressibility, mv, } \\
\text { m²/MN }^{2}\end{array}$ & 0.33 & 0.44 & 0.38 \\
\hline
\end{tabular}

The near surface soil encountered as revealed in this study is firm clay extending from the ground level to a depth of 2.0 below the ground surface and extending to $5.0 \mathrm{~m}$ in borehole 3 . This firm clay is characterized by moderate compressibility, low moisture content and low undrained strength. The range of variations in the index and engineering parameters of this near surface soil are shown in Table 3.

\subsection{Loose and Medium Dense Sand}

Loose to medium dense sand was encountered immediately beneath the near surface silty clay soil. This loose to medium dense sand increases in density to becoming dense to very dense sand from about $7.0 \mathrm{~m}$ below the existing ground level. Deeper down in the boring from about $25.0 \mathrm{~m}$, it is observed that the sand loosens to becoming medium dense. This medium dense sand continues to the final depth of the investigation. The ranges of variations of the geotechnical parameters are shown Table 4.

Table 4. Range of variations of the geotechnical parameters

\begin{tabular}{|c|c|c|}
\hline & Minimum & Maximum \\
\hline Effective Particle Size, $\mathrm{d}_{10}(\mathrm{~mm})$ & 0.075 & 0.60 \\
\hline Mean Particle Size, $\mathrm{d}_{30}(\mathrm{~mm})$ & 0.16 & 0.15 \\
\hline Particle Size, $\mathrm{d}_{60}(\mathrm{~mm})$ & 0.16 & 0.45 \\
\hline Coefficient of Uniformity, $\mathrm{Cu}=\mathrm{d}_{60} / \mathrm{d}_{10}$ & 2.82 & 0.45 \\
\hline Coefficient of Curvature, $\mathrm{Cc}=\mathrm{d}_{30}{ }^{2} / \mathrm{d}_{10} \cdot \mathrm{d}_{60}$ & 0.32 & 9.83 \\
\hline
\end{tabular}

The near surface soil is $2.0 \mathrm{~m}$ thick intercalations of clay and sand in boreholes 1 and 2 and a $5.0 \mathrm{~m}$ thick clay layer in borehole 3 . Underlying this near surface clay is a formation of loose sand becoming medium dense and dense sand with depth. The lithology revealed a stratum of graded bed. The upper sand stratum being loose and fine sand immediately beneath the clay layer and grading to become medium dense sand with depth. This gradation continues as the borehole advances and deeper down some loosening of the sand is observed. This loosening is observed to the final depth of the borehole.

Considering the moderate compressibility of the near surface clay and the underlying loose silty sand, it is suggested that any proposed foundation in the area be supported on raft foundations founded in the upper clay. However, where the project precludes the use of raft foundation pile foundation should be employed to transmit the load to the underlying soil stratum.
Table 5. Allowable bearing capacities for various foundation widths

\begin{tabular}{|c|c|c|c|c|c|c|}
\hline \multirow{2}{*}{$\begin{array}{c}\text { Foundation } \\
\text { depth, } \mathrm{D}_{\mathrm{f}}(\mathrm{m})\end{array}$} & \multicolumn{3}{|c|}{$\begin{array}{c}\text { Allowable, } \\
(\mathrm{kPa}), \text { for Various Width, } \mathrm{(kPa}(\mathrm{m}) \text { of Raft Foundation }\end{array}$} \\
\cline { 2 - 7 } & \multicolumn{2}{|c|}{$2 \mathrm{~m}$} & \multicolumn{2}{c|}{$5 \mathrm{~m}$} & \multicolumn{2}{c|}{$10 \mathrm{~m}$} \\
\cline { 2 - 7 } & $\mathrm{Q}_{\text {all }}$ & $\mathrm{Q}_{\mathrm{s}}$ & $\mathrm{Q}_{\text {all }}$ & $\mathrm{Q}_{\mathrm{s}}$ & $\mathrm{Q}_{\text {all }}$ & $\mathrm{Q}_{\mathrm{s}}$ \\
\hline 1 & 98 & 60 & 102 & 52 & 110 & 35 \\
\hline 2 & 104 & 95 & 107 & 75 & 115 & 55 \\
\hline 3 & 109 & 105 & 113 & 110 & 120 & 75 \\
\hline
\end{tabular}

Using a safety factor of 3 on the ultimate bearing capacity, the chart for the allowable bearing capacity is as presented in Figure 3. Table 5 shows allowable, $\mathrm{Q}_{\text {all }}(\mathrm{kPa})$ and safe $\mathrm{Q}_{\mathrm{s}}(\mathrm{kPa})$ bearing capacities for various foundation width, $\mathrm{B}(\mathrm{m})$ of raft footing at different foundation depth, $\mathrm{D}_{\mathrm{f}}, \mathrm{m}$ while Table 6 shows the design parameters for cohesionless soil. Table 7 also shows the allowable bearing capacity and specific pile diameter for specific depths. The safe bearing capacity for the raft foundation is limited by a maximum settlement value of $50 \mathrm{~mm}$. Figure 2 is a chart of ultimate bearing capacity 
versus breadth/length ratio while Figure 3 shows the allowable bearing capacity. Figure $4 \&$ Figure 5 shows the ultimate pile capacity and allowable pile capacity chart, respectively.

Table 6. Design parameters for cohesion-less soil

\begin{tabular}{ccccc}
\hline Soil type & $\delta$ & $\begin{array}{c}\text { Skin friction, } \mathrm{f} \\
(\mathrm{kPa})\end{array}$ & $\mathrm{N}_{\mathrm{q}}$ & $\begin{array}{c}\text { Limiting Unit End } \\
\text { Bearing, }(\mathrm{kPa})\end{array}$ \\
\hline Very loose & 10 & 48 & 8 & 1900 \\
$\quad$ sand & 15 & 67 & 12 & 2900 \\
$\begin{array}{c}\text { Loose sand } \\
\text { Medium dense }\end{array}$ & 20 & 81 & 20 & 4800 \\
$\quad$ sand & 96 & 40 & 9600 \\
Dense sand & 25 & 115 & 50 & 12000 \\
$\begin{array}{c}\text { Very dense } \\
\text { sand }\end{array}$ & 30 & & & \\
\hline
\end{tabular}

Table 7. Allowable bearing capacity and specific pile diameter for specific depths

\begin{tabular}{cccc}
\hline \multirow{2}{*}{$\begin{array}{c}\text { Pile depth } \\
\text { (m) }\end{array}$} & \multicolumn{3}{c}{ Allowable Pile Capacity, kPa, for Various Pile diameter } \\
\cline { 2 - 4 } & 305mm (12”) & 460mm (18”) & $\mathbf{6 1 0 m m ~ ( 2 4 ” ) ~}$ \\
10 & Pile & Pile & Pile \\
15 & 129 & 181 & 272 \\
20 & 291 & 471 & 703 \\
25 & 418 & 685 & 1021 \\
30 & 432 & 673 & 950 \\
\hline
\end{tabular}

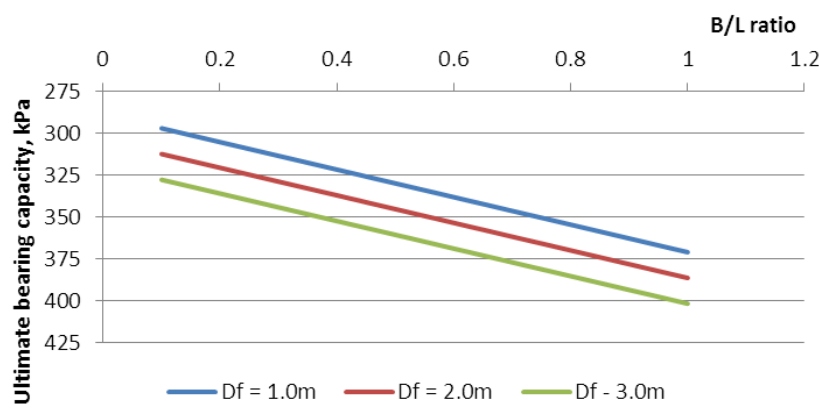

Figure 2. Chart of ultimate bearing capacity Versus Breadth/Length Ratio

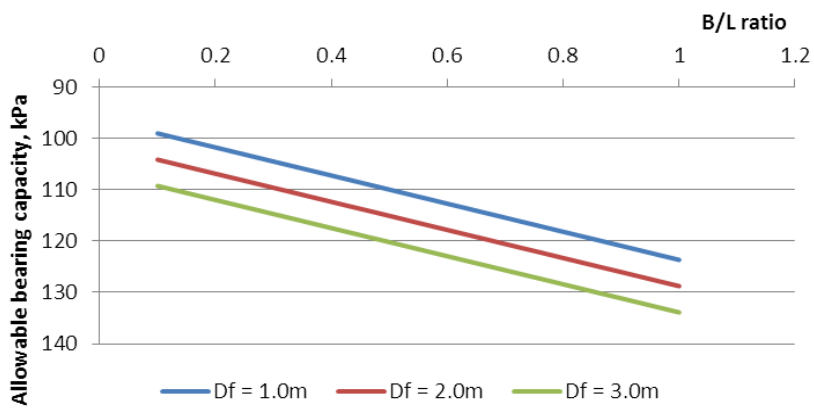

Figure 3. Chart of allowable bearing capacity

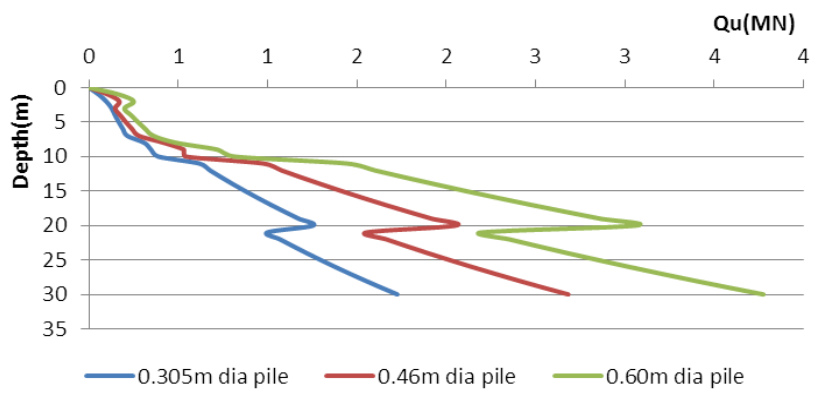

Figure 4. Chart of ultimate Pile capacity

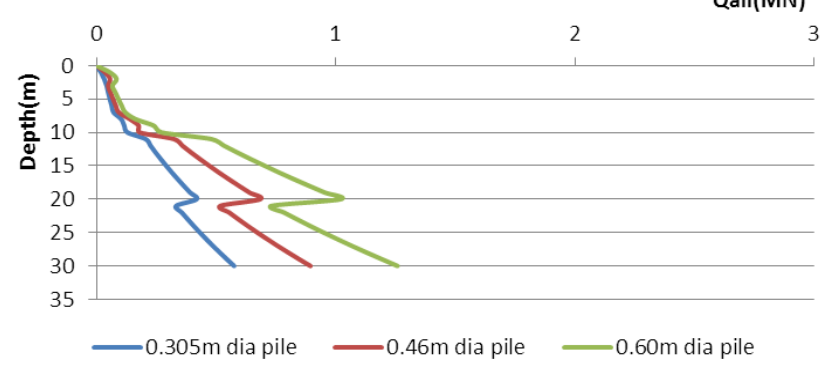

Figure 5. Chart of allowable pile capacity

\section{Conclusion}

This preliminary study revealed a near surface stratigraphy of silty clay to a depth of $5 \mathrm{~m}$ underlain by loose silty sand to a depth of $9.0 \mathrm{~m}$ below the existing ground level. Underlying this layer of loose sand is a 1.0 $\mathrm{m}$ thick layer of plastic clay. Considering the moderate compressibility of the near surface silty clay and the underlying loose silty sand, it is suggested that proposed structures in the area be supported by means of raft foundation founded within the upper clay layer where it is uneconomical to take it deeper. The plastic clay beneath will undergo consolidation along with the compression and creep that will result from loading the loose sand beneath it. Adequate consideration should be taken of this settlement during the design and construction stages in the area.

\section{References}

[1] Amadi, A.N; Eze, C.J; Igwe, C.O; Okunlola, I.A. and Okoye, N.O (2012). Architect's and geologist's view on the causes of building failures in Nigeria. Modern Applied Science, Vol. 6 (6): 31-38.

[2] Amadi, A. N; Olasehinde, P. I; Okunlola, I. A; Okoye, N. O. and Waziri, S (2010). A multidisciplinary approach to subsurface characterization in Northwest of Minna, Niger State, Nigeria. Bayero Journal of Physics and Mathematical Sciences, 3 (1), 7483.

[3] ASTM (1979). Annual Book of America Society for Testing and Materials Standards, 1289, Philadelphia, ASTM Tech. Publ. 630pp.

[4] British Standard Methods of Test for soils for Civil Engineering Purposes. B.S 1377: Part 2, 1990. Published by the British Standards Institution, pp 8-200.

[5] Etu-Efeotor, J.O and Akpokodje, E.G (1990). Aquifer systems of the Niger Delta. Journal of Mining Geology, 26 (2): 279-284.

[6] Haddou, M.B; Essahlaoui, A; Boujlal, M; Elouali, A; and Hmaidi, A (2013). Study of the geotechnical parameters of the different soils by correlation analysis and statistics in the Kenitra Region of Morocco. Journal of Earth Sciences and Geotechnical Engineering, 3 (2): 51-60.

[7] Merki, J.P. (1970). Structural Geology of the Cenozoic Niger Delta. African Geology. University of Ibadan Press. pp 251-268.

[8] Murat, R.C (1970). Stratigraphy and Paleogeography of the Cretaceous and Lower Tertiary in Southern Nigeria. In: Dessauvagie, T.T J and Whiteman, A.J (eds.). African Geology, University of Ibadan Press, Ibadan, Nigeria. Pp 251-266.

[9] Ngah, S.A and Nwankwoala, H.O (2013). Evaluation of Geotechnical Properties of the Sub-soil for Shallow Foundation Design in Onne, Rivers State, Nigeria. The Journal of Engineering and Science, Vol. 2 (11): 08-16.

[10] Nwankwoala, H.O and Warmate, T (2014). Geotechnical Assessment of Foundation Conditions of a Site in Ubima, Ikwerre Local Government Area, Rivers State, Nigeria. International Journal of Engineering Research and Development (IJERD) 9 (8): 50-63. 
[11] Oke, S. A and Amadi, A. N (2008). An Assessment of the Geotechnical Properties of the Subsoil of parts of Federal University of Technology, Minna, Gidan Kwano Campus, for Foundation Design and Construction. Journal of Science, Education and Technology, 1 (2), 87-102.

[12] Oghenero, A.E; Akpokodje, E.G and Tse, A.C (2014) Geotechnical Properties of Subsurface Soils in Warri, Western Niger Delta, Nigeria. Journal of Earth Sciences and Geotechnical Engineering, 4 (1): 89-102.

[13] Reyment, R.A (1965). Aspects of the Geology of Nigeria, University of Ibadan Press, p 133
[14] Short, K. C. and Stauble, A. J. (1967). Outline of Geology of the Niger Delta. American Association of Geologists, Vol. 51, No. 5, pp. 761-779.

[15] Youdeowei, P.O and Nwankwoala, H.O (2010). Assessment of some geo-environmental problems associated with road construction in the Eastern Niger Delta. Afr. J. Environ. Pollut. Health, Vol. 8 (1): 1-7.

[16] Youdeowei, P.O and Nwankwoala, H.O (2013). Suitability of soils as bearing media at a freshwater swamp terrain in the Niger Delta. Journal of Geology and Mining Research, Vol. 5 (3): k58-64. 